\title{
STUDI KOMPARATIF PEMBERIAN AIR SUSU IBU (ASI) DAN GLUKOSA 30\% TERHADAP RESPON NYERI NEONATUS YANG DILAKUKAN TINDAKAN INVASIF DI RUMAH SAKIT ABDUL MOELOEK PROVINSI LAMPUNG
}

\author{
Sri Suharti \\ Akademi Keperawatan Baitul Hikmah Bandar Lampung \\ Email: srisuharti1977@gmail.com
}

\begin{abstract}
Abstrack: Comparation Studies of Giving Breast Feeding and Glucose 30\% to Neonatus"s Pain Response. Neonates that were hospitalized, often got invasive procedure that causes pain. Invasive procedures in 54 neonates that were in the NICU, there were occur 3283 times acts that cause pain during treatment. Pain is an unpleasant experience due to tissue damage, that have subjective nature can be assessed from facial expressions, body movements, crying and break. The pain scale were using the Neonatal Infant Pain Scale (NIPS). This study was to compare the combination of breast feeding and NNS to combination glucose 30\% and NNS, for neonatal pain response during applying infusion or taking blood specimen, in A hospital of Lampung Province. It was a quasi experiment with comparison group design (static group comparism). Sample were neonates aged 0-28 which was applied infusion or taken blood specimen, consist of 16 respondents as group of NNS combination with breast feeding and 16 respondents as group of NNS intervention combination with glucose $30 \%$. Differences of pain response during infusion or taking blood specimen were analyzed by independent sample t-test. The results showed that there was no significant difference between the combination group of NNS with breast feeding and the group of NNS combination with glucose $30 \%$ ( $\mathrm{p}=0.076$ ). Based on this study, it was recommended that NNS with breast feeding and NNS with glucose 30\%, both can be used as a nonpharmacological therapy management in neonates while applying infusion or taking blood specimen.
\end{abstract}

Keywords: Breast Feeding, Glucose 30\%, Non nutritive sucking, Neonates pain, Applying infusion and taking blood specimen

\begin{abstract}
Abstrak: Studi Komparatif Pemberian Air Susu Ibu(ASI) dan Glukosa 30\% terhadap Respon Nyeri Neonatus yang Dilakukan Tindakan infasiv di Rumah Sakit Abdul Moeloek Provinsi Lampung. Neonatus yang dirawat di rumah sakit sering mendapatkan tindakan invasif yang menimbulkan nyeri. Prosedur invasif pada 54 neonatus yang dirawat di NICU terjadi 3283 kali tindakan yang menyebabkan nyeri selama masa perawatan. Nyeri adalah pengalaman tidak menyenangkan akibat kerusakan jaringan bersifat subjektif dapat dinilai dari ekspresi wajah, gerakan tubuh, menangis dan istirahat dengan skala nyeri yang dapat digunakan adalah Neonatal Infant Pain Scale (NIPS). Tujuan penelitian untuk membandingkan pemberian kombinasi NNS dengan ASI dan kombinasi NNS dengan glukosa 30\% terhadap respon nyeri neonatus saat pemasangan infus atau pengambilan spesimen darah di rumah sakit A Provinsi Lampung. Desain penelitian adalah quasi experimental dengan rancangan perbandingan kelompok (static group comparism). Sampel yaitu neonatus usia 0-28 hari yang dilakukan tindakan pemasangan infus atau pengambilan spesimen darah yang terdiri dari 16 responden kelompok kombinasi NNS dengan ASI dan16 responden kelompok intervensi kombinasi NNS dengan glukosa 30\%. Analisis perbedaan respon nyeri saat pemasangan infus atau pengambilan spesimen darah menggunakan independent sampel $t$-Test. Hasil penelitian menunjukkan bahwa tidak ada perbedaan yang signifikan antara kelompok kombinasi NNS dengan ASI dan kelompok kombinasi NNS dengan glukosa 30\% $(p=0,076)$. Berdasarkan hasil penelitian direkomendasikan bahwa NNS dengan ASI atau NNS dengan glukosa 30\% sama-sama dapat digunakan sebagai manejemen terapi non farmakologi pada neonatus yang dilakukan pemasangan infus atau pengambilan spesimen darah.
\end{abstract}

Kata kunci: ASI, Glukosa 30\%, NNS dan, Nyeri neonatus, Pemasangan infus dan pengambilan spesimen darah 

Nyeri merupakan suatu pengalaman sensorik dan emosional yang tidak menyenangkan dan merupakan tanda akan adanya kerusakan jaringan. Nyeri pada neonatus menjadi masalah oleh karena neonatus tidak dapat memberitahu rasa nyeri, kesulitan mengenali tangisan dan mimik wajah neonatus sebagai tanda rasa nyeri dan sulit menentukan kapan sebaiknya memberi analgesia pada neonatus (Triani \& Lubis, 2006). The International Association for the Study of Pain juga menetapkan bahwa nyeri bersifat subjektif dan dipelajari melalui pengalaman yang berhubungan dengan luka pada awal kehidupan.

Neonatus yang dirawat di ruang intensif sering sekali mengalami prosedur invasif yang dapat menimbulkan nyeri. Tindakan invasif adalah tindakan medis keperawatan berupa memasukkan atau melukai jaringan yang dimasukkan melalui organ tubuh tertentu (Menurut American Heart Association (AHA) tahun 2003 dalam Bolin 2011). Penelitian yang dilakukan oleh Malarvizhi, Vasta, Roseline, Nithin dan Paul (2012) menjelaskan bahwa sejumlah prosedur invasif terhadap 54 neonatus yang dirawat di NICU menunjukkan bahwa terdapat 3283 kali tindakan yang dapat menyebabkan nyeri selama masa perawatan. Tindakan yang dapat menyebabkan nyeri tersebut terdiri dari $55 \%$ tindakan heel lance, $26 \%$ nyeri disebabkan oleh suction endotracheal dan $15 \%$ nyeri disebabkan oleh efek pemasangan infus intra vena. Obu dan Chinawa (2014) menyebutkan dalam review artikel nya bahwa neonatus prematur yang dirawat dirumah sakit rata-rata mengalami 750 prosedur tindakan. Hal ini mencatat bahwa bayi prematur yang dirawat di NICU menjadi sasaran rata-rata dua sampai delapan prosedur yang menyakitkan perhari. Terapi non farmakologis direkomendasikan untuk mengatasi nyeri ringan karena efeknya jangka pendek dengan toleransi yang baik (Kashaninia, 2008).Analgesik non farmakologi dipakai untuk prosedur yang lebih ringan rasa nyerinya (tindakan invasif minor). Penanganan non farmakologis dalam penanganan masalah nyeri pasien merupakan tindakan yang bersifat aman, non invasif, tidak mahal dan merupakan tindakan keperawatan yang dapat dilakukan secara mandiri (Hockenberry \& Wilson, 2009). Intervensi non-farmakologi yang dapat dilakukan pada bayi baru lahir untuk mengurangi respon sakit selama prosedur invasif diantaranya adalah air susu ibu (ASI) dan Glukosa.

Studi pendahuluan ini dilakukan di Rumah Sakit A, merupakan rumah sakit tipe B dan merupakan rujukan di provinsi lampung yang mempunyai ruang perinatologi. Ruang perinatologinya terdiri dari level IIA, IIB, dan level III. Menurut statistik ruang perinatologi rumah sakit A Provinsi lampung menunjukan angka neonatus yang dirawat pada bulan Oktober sampai Desember 2014 adalah 81 bayi pada bulan Oktober, 74 bayi pada bulan November, dan 61 bayi pada bulan Desember. Bayi tersebut dilakukan tindakan pemasangan infus untuk memenuhi kebutuhan nutrisi atau obat melalui jalur parenteral, mempertahankan keseimbangan cairan dan elektrolit. Berdasarkan observasi dan wawancara diruangan perinatologi didapatkan bahwa bayi yang dirawat di perinatologi baik level IIA, IIB, dan III belum dilakukan prosedur Peripherally Inserted Central Catheter (PICC) sehingga bayi sering dilakukan pergantian infus.

Selain prosedur invasif pemasangan infus yang paling banyak dilakukan pada neonatus yang dirawat diruang perinatologi, pengambilan spesimen darah juga merupakan prosedur invasif tersering yang dilakukan. Adapun saat melakukan tindakan invasif pemasangan infus dan pengambilan spesimen darah petugas tidak melakukan intervensi apapun untuk mengurangi respon nyeri pada neonatustersebut, terkadang ada faktor penyulit sehingga tidak bisa dilakukan satu kali penusukan pemasangan infus maupun pengambilan spesimen darah. Hal ini tentunya akan menambah stres dan bisa berdampak negatif pada masa perkembangan neonatus selanjutnya. Penusukan pada area kulit atau prosedur invasif menyebabkan rasa nyeri sehingga memerlukan penatalaksanaan nyeri yang adekuat dan disesuaikan dengan kondisi neonatus untuk mencegah akibat akut maupun jangka panjang guna meningkatkan kualitas anak di masa mendatang sebagai investasi bangsa.

Penelitian ini bertujuan untuk membandingkan efektivitas pemberian kombinasi Non Nutritive Sucking dengan ASI dan kombinasi NNS dengan glukosa 30\% terhadap respon nyeri neonatus yang dilakukan prosedur invasif pemasangan infus atau pengambilan spesimen darah vena di ruang perinatologi rumah sakit A Provinsi Lampung.

\section{METODE PENELITIAN}

Disain yang digunakan dalam penelitian ini adalah quasi experimental dengan rancangan perbandingan kelompok statis (static group comparism) yaitu kelompok intervensi pertama menerima perlakuan (X1), kemudian dilakukan pengukuran. Hasil observasi ini dibandingkan dengan hasil observasi pada kelompok intervensi 
kedua yang menerima perlakuan (X2) (Setiadi, 2007). Pada penelitian ini membandingkan dua kelompok intervensi. Satu kelompok intervensi menerima perlakuan pemberian kombinasi NNS dengan ASI dan yang satunya lagi menerima perlakuan pemberian kombinasi NNS dengan glukosa $30 \%$, yang diikuti dengan pengukuran skala nyeri neonatus menggunakan skala NIPS. Waktu penelitian Waktu penelitian dilakukan mulai dari 8 April sampai dengan bulan 28 Mei 2015.

Populasi dalam penelitian ini adalah seluruh neonatus yang dirawat di ruang perinatologi RSUD dr. H. Abdul Moeloek Provinsi Lampung yang dilakukan tindakan pemasangan infus atau pengambilan spesimen darah. Sampel dalam penelitian ini adalah neonatus usia $\leq 28$ hari dirawat di ruang perinatologi RSUD dr. H. Abdul Moeloek Provinsi Lampung yang sesuai dengan kriteria inklusi yang ditetapkan oleh peneliti. Tehnik pengambilan sampel dalam penelitian ini dilakukan dengan cara consecutive sampling yang merupakan non-probability sampling yaitu pemilihan sampel yang dilakukan dengan memilih semua individu yang ditemui dan memenuhi kriteria penelitian sampai jumlah sampel yang diinginkan terpenuhi (Dharma, 2011)

Pengumpulan data dilakukan dengan menilai respon nyeri neonatus yang dilakukan pemasangan infus atau pengambilan spesimen darah vena pada kedua kelompok intervensi. Pengumpulan data penelitian yang dilakukan dibagi beberapa tahapan antara lain:

Prosedur teknis penelitian yang dilakukan peneliti adalah:

1. Meminta izin kepada Direktur, Kepala Bidang Pelayanan dan Kepala Seksi Keperawatan, Ka SMF dan kepala ruangan perinatologi untuk mensosialisasikan maksud dan tujuan penelitian kepada tim keperawatan.

2. Sebelum pengumpulan data dilakukan, peneliti melakukan sosialisasi tentang penilaian respon nyeri neonatus dengan menggunakan instrumen NIPS kepada perawat perinatologi.

3. Menentukan responden yang memenuhi kriteria inklusi sesuai dengan teknik pengambilan sampel.

4. Pengambilan data dilakukan sendiri oleh peneliti dengan menilai respon nyeri neonatus berdasarkan skala NIPS, peneliti meminta bantuan 2 asisten peneliti hanya untuk membantu merekam respon nyeri neonatus, 30 detik sebelum tindakan pemasangan infus atau pengambilan spesimen darah dilakukan, respon nyeri klien direkam dengan menggunakan kamera digital sampai 1 menit setelah prosedur atau tangisan neonatus berhenti, peneliti disini berperan untuk menghitung pola nafas bayi yang merupakan penilaian dari skala NIPS.

5. Kelompok intervensi 1

a. Meminta kesediaan orang tua atau penanggung jawab subjek penelitian mengizinkan neonatus yang sesuai kriteria inklusi untuk menjadi subjek penelitian.

b. Menjelaskan tujuan penelitian yaitu untuk membandingkan efektifitas pemberian kombinasi NNS dengan ASI terhadap respon nyeri neonatus yang dilakukan tindakan pemasangan infus atau pengambilan spesimen darah vena

c. Memberikan kesempatan kepada orang tua atau penanggung jawab subjek penelitian untuk menanyakan hal yang berkaitan dengan prosedur penelitian.

d. Meminta dengan sukarela orang tua atau penanggung jawab subjek penelitian untuk menandatangani informed consent. Pada saat orang tua/ penanggung jawab responden tidak berada ditempat peneliti berusaha mencari supaya orang tua/ penanggung jawab datang keruangan.

e. Menyiapkan ASI $2 \mathrm{~mL}$

f. Menempatkan neonatus di bawah radiant warmer dengan kondisi hanya menggunakan pampes dan alas yang bersih.

g. Memposisikan bayi berada dalam keadaan tenang dan tidak menangis saat dilakukan pemasangan infus atau pengambilan spesimen darah.

h. Dot dari silikon dioleskan kedalam $2 \mathrm{ml}$ ASI dan sisanya diinjeksikan ke dalam dot.

i. Memberikan dot dari silikon yang sudah diberi ASI ke mulut neonatus 2 menit sebelum tindakan pemasangan infus atau pengambilan spesimen darah vena dilakukan.

j. Dot dari silikon dihisap oleh neonatus dan dibantu oleh perawat untuk mengantisipasi agar dot tidak terlepas dari mulut neonatus.

k. Perawat ruangan melakukan pemasangan infus atau pengambilan spesimen darah vena sesuai prosedur tetap pemasangan infus atau pengambilan spesimen darah di rumah sakit A Provinsi Lampung. 
1. Merekam proses pemasangan infus atau pengambilan spesimen darah vena 30 detik sebelum penusukan sampai 1 menit setelah penusukan dengan menggunakan kamera digital.

m. Merapikan kembali neonatus dan mengembalikan ke inkubator atau box bayi yang sudah ditetapkan.

n. Melakukan penyimpanan data penelitian.

o. Melakukan penilaian respon nyeri neonatus dengan menggunakan skala NIPS.

p. Penilaian respon nyeri neonatus yang dilakukan pemasangan infus atau pengambilan spesimen darah vena pada kelompok intervensi 1 dilakukan melalui pemutaran ulang video yang dilakukan 23 kali untuk setiap subjek penelitian untuk memastikan respon subjek penelitian.

6. Kelompok intervensi 2

a. Meminta kesediaan orang tua atau penanggung jawab subjek penelitian mengizinkan neonatus yang sesuai kriteria inklusi untuk menjadi subjek penelitian.

b. Menjelaskan tujuan penelitian yaitu untuk membandingkan efektifitas pemberian kombinasi NNS dan glukosa $30 \%$ terhadap respon nyeri neonatus yang dilakukan tindakan pemasangan infus atau pengambilan spesimen darah vena

c. Memberikan kesempatan kepada orang tua atau penanggung jawab subjek penelitian untuk menanyakan hal yang berkaitan dengan prosedur penelitian.

d. Meminta dengan sukarela orang tua atau penanggung jawab subjek penelitian untuk menandatangani informed consent.

e. Menyiapkan caira glukosa $30 \%$ sebanyak $2 \mathrm{~mL}$ dan dot

f. Menempatkan neonatus di bawah radiant warmer dengan kondisi hanya menggunakan pampes dan alas yang bersih.

g. Memposisikan bayi berada dalam keadaan tenang dan tidak menangis saat akan dilakukan pemasangan infus atau pengambilan spesimen darah.

h. Dot dari silikon dioleskan kedalam $2 \mathrm{ml}$ glukosa $30 \%$ dan sisanya dimasukkan ke dalam dot

i. Memberikan dot dari silikon yang sudah diberi glukosa 30\% ke mulut neonatus 2 menit sebelum tindakan pemasangan infus atau pengambilan spesimen darah vena dilakukan

j. Dot dari silikon dihisap oleh neonatus dan dibantu oleh perawat untuk mengantisipasi agar dot tidak terlepas dari mulut neonatus.

k. Merekam proses pemasangan infus atau pengambilan spesimen darah vena 30 detik sebelum penusukan sampai 1 menit setelah penusukan dengan menggunakan kamera digital.

1. Perawat ruangan melakukan pemasangan infus atau pengambilan spesimen darah vena sesuai prosedur tetap pemasangan infus atau pengambilan spesimen darah di RSUD dr. H. Abdul Moeloek Provinsi Lampung.

m. Merapikan kembali neonatus dan mengembalikan ke inkubator atau box bayi yang sudah ditetapkan.

n. Melakukan penyimpanan data penelitian.

o. Melakukan penilaian respon nyeri neonatus dengan menggunakan skala NIPS.

p. Penilaian respon nyeri neonatus yang dilakukan pemasangan infus atau pengambilan spesimen darah vena pada kelompok intervensi 2 dilakukan melalui pemutaran ulang video yang dilakukan 23 kali untuk setiap subjek penelitian untuk memastikan respon subjek penelitian.

\section{HASIL}

\section{A. ANALISIS UNIVARIAT}

Tabel 1. Distribusi Responden Berdasarkan Usia Neonatus

\begin{tabular}{llrrrr}
\hline Variabel & Intervensi & Rata-rata & SD & Min-Max & 95\% CI \\
\hline Usia & ASI & 9,44 & 8,058 & $2-27$ & $5,14-13,73$ \\
neonatus & Glukosa 30\% & 8,75 & 7,312 & $2-28$ & $4,60-12,40$ \\
\hline
\end{tabular}


Tabel 2. Distribusi Responden Berdasarkan Usia Gestasi, Jenis Kelamin, Jenis Penyakit, dan Riwayat Pemasangan Infus

\begin{tabular}{llrrrr}
\hline & \multirow{2}{*}{ Karakteristik } & \multicolumn{2}{c}{ Kelompok } & \multicolumn{2}{c}{ Kelompok } \\
& & \multicolumn{2}{c}{ ASI } & \multicolumn{2}{c}{ Glukosa 30\% } \\
\cline { 3 - 6 } & & n & \% & \multicolumn{1}{c}{ n } & \% \\
\hline \multirow{2}{*}{ Usia Gestasi } & $34-36 \mathrm{mgg}$ & 4 & 25,0 & 7 & 43,8 \\
& $\geq 37 \mathrm{mgg}$ & 12 & 75,0 & 9 & 56,3 \\
\hline \multirow{2}{*}{ Jenis kelamin } & Laki-laki & 8 & 50,0 & 9 & 56,3 \\
& Perempuan & 8 & 50,0 & 7 & 43,8 \\
\hline Riwayat Pemasangan infus & Belum pernah & 1 & 6,3 & 2 & 12,5 \\
dan pengambilan darah & Sudah Pernah & 15 & 93,8 & 14 & 87,5 \\
\hline \multirow{3}{*}{ Jenis Penyakit } & BBLR & 2 & 12,5 & 4 & 25,0 \\
& Sepsis & 0 & 0,0 & 4 & 25,0 \\
& Hiperbilirubin & 3 & 18,8 & 5 & 31,3 \\
& Kelainan bawaan selain neurologis dan mulut & 11 & 68,8 & 3 & 18,8 \\
\hline
\end{tabular}

Tabel 3. Hasil Analisis Respon Nyeri Pemasangan Infus atau Pengambilan Spesimen Darah pada Neonatus

\begin{tabular}{ccrcrc}
\hline Variabel & Intervensi & Rata-rata & SD & Min-Max & 95\%CI \\
\hline NIPS & ASI & 2,50 & 2,422 & $0-6$ & $1,21-3,79$ \\
& Glukosa30\% & 1,19 & 1,471 & $0-4$ & $0,40-1,97$ \\
\hline
\end{tabular}

Dapat disimpulkan yaitu rata-rata respon nyeri neonatus pada saat dilakukan tindakan pemasangan infus atau pengambilan spesimen darah yang diukur dengan skala nyeri NIPS pada kelompok perlakuan ASI adalah 2,50, dengan standar deviasi 2,422. Sementara itu skala nyeri terendah pada kelompok perlakuan ASI adalah 0 dan skala nyeri tertinggi adalah 6 . Hasil estimasi interval dapat disimpulkan bahwa 95\% diyakini bahwa rata-rata tingkat nyeri yang diukur dengan NIPS pada kelompok perlakuan ASI diantara 1,21- 3,79. Hasil analisa kelompok perlakuan glukosa $30 \%$ menunjukkan rata-rata skala nyeri neonatus saat pengambilan spesimen darah atau pemasangan infus yang diukur dengan skala nyeri NIPS adalah 1,19 , dengan standar deviasi 1,471. Sementara itu skala nyeri terendah untuk kelompok perlakuan glukosa $30 \%$ adalah 0 dan tertinggi adalah 4. Hasil estimasi interval dapat disimpulkan bahwa 95\% diyakini rata-rata respon nyeri bayi yang diberikan perlakan glukosa $30 \%$ yang diukur dengan menggunakan skala nyeri NIPS berada antara 0,40-1,97. Artinya pada derajat keyakinan $95 \%$ (kesalahan $5 \%$ di estimasi rata-rata skala nyeri pada kelompok glukosa $30 \%$ berada dalam rentang $0,40-1,97$.

Tabel 4. Hasil Analisis Kesetaraan Karakteristik Responden Kelompok ASI dan Kelompok Glukosa 30\%

\begin{tabular}{|c|c|c|c|c|}
\hline \multicolumn{2}{|c|}{ Karakteristik } & $\begin{array}{c}\text { Kelompok } \\
\text { ASI }\end{array}$ & $\begin{array}{c}\text { Kelompok } \\
\text { Glukosa } 30 \% \\
\end{array}$ & $p$-value \\
\hline \multirow{3}{*}{ Usia Gestasi } & & & & \multirow{3}{*}{0,053} \\
\hline & $34-36 \mathrm{mgg}$ & 4 & 7 & \\
\hline & $\geq 37 \mathrm{mgg}$ & 12 & 9 & \\
\hline \multirow{2}{*}{ Jenis kelamin } & Laki-laki & 8 & 9 & \multirow[t]{2}{*}{0,629} \\
\hline & Perempuan & 8 & 7 & \\
\hline \multirow{2}{*}{$\begin{array}{l}\text { Riwayat Pemasangan infus } \\
\text { atau pengambilan darah }\end{array}$} & Belum pernah & 1 & 2 & \multirow{2}{*}{0,237} \\
\hline & Sudah Pernah & 15 & 14 & \\
\hline \multirow{4}{*}{ Jenis Penyakit } & BBLR & 2 & 4 & \multirow{4}{*}{0,433} \\
\hline & Sepsis & 0 & 4 & \\
\hline & Hiperbilirubin & 3 & 5 & \\
\hline & $\begin{array}{l}\text { Kelainan bawaan selain } \\
\text { neurologis dan mulut }\end{array}$ & 11 & 3 & \\
\hline \multicolumn{2}{|l|}{ Usia neonatus } & & & 0,479 \\
\hline
\end{tabular}

Berdasarkan pada hasil uji statistik maka dapat disimpulkan uji kesetaraan tentang umur neonatus, usia gestasi, jenis kelamin, riwayat pemasangan infus dan tindakan invasif sebelumnya, jenis penyakit menunjukkan nilai $(p>0,05)$, hal ini menunjukan tidak ada perbedaan antara neonatus yang diberikan NNS dan ASI dengan neonatus yang diberikan NNS dan glukosa $30 \%$ atau antara kedua kelompok setara. 


\section{B. HASIL ANALISIS BIVARIAT}

Tabel 5. Uji Normalitas Kelompok ASI dan Kelompok Glukosa 30\%

\begin{tabular}{lc}
\hline \multicolumn{1}{c}{ Variabel } & Skweness/SE \\
\hline Respon nyeri ASI & 0,514 \\
Respon nyeri glukosa $30 \%$ & 1,641 \\
\hline
\end{tabular}

Tabel 6. Hasil Analisis Perbandingan Rata-Rata Respon Nyeri Skala Sakit

\begin{tabular}{lccccc}
\hline $\begin{array}{l}\text { Skala } \\
\text { nyeri }\end{array}$ & $\begin{array}{c}\text { Rata- } \\
\text { rata }\end{array}$ & SD & SE & $\begin{array}{c}p- \\
\text { value }\end{array}$ & n \\
\hline $\begin{array}{l}\text { Diberi } \\
\text { ASI }\end{array}$ & 2,50 & 2,422 & 0,606 & & 16 \\
$\begin{array}{l}\text { Diberi } \\
\text { glukosa }\end{array}$ & 1,19 & 1,471 & 0,368 & & 16 \\
$30 \%$ & & & & & \\
\hline
\end{tabular}

Hasil penelitan didapatkan bahwa rata-rata respon nyeri neonatus yang diberikan perlakuan ASI adalah 2,50 dengan standar deviasi 2,422, sedangkan neonatus yang diberikan glukosa $30 \%$ rata-rata respon nyerinya adalah 1,19 dengan standar deviasi 1,471. Hasil uji statistik didapatkan nilai $p=0,076$, berarti pada alpha $5 \%$ terlihat tidak ada perbedaan yang signifikan ratarata respon nyeri neonatus antara kelompok intervensi kombinasi NNS dan ASI dengan kelompok intervensi NNS dan glukosa $30 \%$.

\section{PEMBAHASAN}

\section{Karakteristik Responden}

Karakteristik yang diukur untuk melihat kontribusinya terhadap respon nyeri neonatus yang dilakukan pemasangan infus atau pengambilan spesimen darah pada penelitian ini yaitu usia neonatus, usia gestasi, jenis kelamin, riwayat/ pengalaman pemasangan infus atau pengambilan spesimen darah dan jenis penyakit.

Rata-rata umur dalam hari yang terendah adalah pada kelompok kombinasi NNS dengan ASI yaitu 2 hari dan usia tertua adalah kelompok kombinasi NNS dengan glukosa $30 \%$ yaitu 28 hari. Hal ini terkait dengan tempat pengambilan responden yang diperoleh diruang neonatus. Neonatus adalah bayi yang berusia kurang dari 28 hari (Hockenbery \& Wilson, 2009). Hasil penelitian ini juga terkait dengan pengambilan sampel penelitian yang didasarkan pada kriteria inklusi.

Persentase pada usia gestasi pada kelompok intervensi NNS dengan ASI usia 34-36 minggu adalah $25,0 \%$ dan persentase usia gestasi 34-36 minggu kelompok glukosa 30\% adalah $43,8 \%$. Sedangkan usia gestasi yang $\geq 37$ minggu kelompok kombinasi NNS dengan ASI adalah
$75,0 \%$ sedangkan kelompok NNS dengan glukosa $30 \%$ adalah $56,3 \%$. Hal tersebut sesuai dengan angka perbandingan 1 dari 10 bayi dimana 10 antara 10 bayi yang lahir hanya 1 yang prematur (WHO, 2012). Hal ini menunjukkan bahwa perbandingan bayi yang lahir prematur lebih sedikit dari pada yang tidak prematur.

Persentase pada karakteristik jenis kelamin pada kedua kelompok adalah sama yaitu laki-laki $50 \%$ dan perempuan $50 \%$. Hal ini terkait dengan responden yang ada pada saat pengambilan data yang disesuaikan dengan kriteria inklusi.

Persentase karakteristik pernah dilakukan prosedur invasif yang terbanyak adalah pernah dilakukan pada kelompok kombinasi NNS dengan ASI adalah 93,8, kelompok glukosa 30\% adalah $87,5 \%$. Hal ini sesuai dengan penelitian Malarvizhi, et al (2012) yang menjelaskan bahwa 54 neonatus yang dirawat di NICU mendapatkan 3283 kali tindakan yang dapat menyebabkan nyeri selama dirawat, artinya neonatus yang dirawat memang sering mendapatkan tindakan invasif.

Persentase karakteristik jenis penyakit yang banyak pada keempat kelompok adalah kelainan bawaan selain mulut dan neurologis sebanyak $68,8 \%$. Hal ini terkait dengan angka kejadian kelainan kongenital sebanyak 15 per 1000 kelahiran (Depkes, 2010).

Dalam penelitian ini dilakukan uji kesetaraan karakteristik responden. Hasil uji kesetaraan untuk variabel umur neonatus, usia gestasi, jenis kelamin, riwayat/ pengalaman pemasangan infus atau pengambilan spesimen darah, serta jenis penyakit adalah setara. Menurut pendapat Polit, Beck dan Hungler (2001), hasil penelitian dikatakan valid jika karakteristik responden adalah sama. Menurut Setiadi (2007), kesetaraan karakteristik antara kedua kelompok intervensi harus diukur, karena jika pada awal dilakukan penelitian kedua kelompok mempunyai sifat yang sama, maka perbedaan hasil penelitian setelah diberikan intervensi adalah pengaruh dari intervensi yang diberikan dan bukan merupakan kontribusi dari pengaruh karakteristik kelompok.

\section{Perbedaan Respon Nyeri Kelompok Intervensi ASI dan Kelompok Intervensi Glukosa 30\%}

Respon nyeri neonatus saat dilakukan prosedur invasif yang diukur dengan skala nyeri NIPS antara kelompok kombinasi NNS dengan ASI dan NNS dengan glukosa 30\%. Hasil penelitian menunjukkan bahwa tidak ada perbedaan yang signifikan, dengan nilai $p=0,076$. Hal ini sesuai dengan penelitian yang dilakukan 
Simonse, et al. (2012) yang juga membandingkan ASI dengan sukrosa pada prosedur heel lance bayi prematur, Simonse menjelaskan bahwa tidak ada perbedaan yang signifikan, nilai rata-rata menunjukkan perbedaan, pada kelompok ASI 6,1 dan kelompok sukrosa nilai rata-rata adalah 5,5 dengan perbedaan rata-rata 0,6 pada kepercayaan $95 \%, \mathrm{p}=0,58$. Sehingga dapat disimpulkan bahwa ASI tidak memiliki efek analgetik lebih baik daripada sukrosa, begitu juga dengan sukrosa juga tidak memiliki efek analgetik lebih baik dari pada ASI.

Hasil penelitian ini berbeda dengan penelitian yang dilakukan oleh Sabety, et al. (2013) terhadap 121 neonatus aterm yang dilakukan prosedur venipuncture dengan metode penelitian menggunakan case control study yang dibagi menjadi 4 kelompok dan 1 kelompok sebagai kelompok kontrol, penelitian ini bertujuan untuk membandingkan efek dari $2 \mathrm{cc}$ glukosa oral $(50 \%)$, aplikasi lidokain, 2 cc ASI melalui syringe yang diberikan 2 menit sebelum prosedur, kemudian dinilai 1 sampai 3 menit setelah prosedur. Penilaian respon nyerinya dengan menggunakan skala nyeri Douleur Aigue Nouveau-ne (DAN). Sabety menunjukkan bahwa ASI lebih efektif dibanding glukosa dan topikal lidokain $(\mathrm{p}<0,05)$. Hal ini juga didukung oleh penelitian Sahoo, et al. (2012) juga menemukan bahwa ASI lebih efektif dibandingkan dengan D $25 \%$ dan air steril. Demikian juga dengan penelitian Yang, et al. (2012) menjelaskan meskipun susu tidak secara signifikan mengurangi waktu menangis, tetapi ditemukan rasa sakit secara signifikan lebih rendah pada kelompok ASI $(p=<0,05)$, hal ini menunjukkan bahwa ASI dapat mengurangi rasa sakit terkait dengan heel lancing pada neonatus prematur.

ASI diduga dapat menurunkan nyeri karena ASI dapat bermanfaat sebagai analgesik yang mengandung sweet solution berbentuk karbohidrat dalam jumlah besar dari total kalori ASI. Karbohidrat dalam ASI terdiri dari laktosa, glukosa, galaktosa, dan glukosamin (Lawrence \& lawrence. 2005, dalam Hockenberry \& Wilson, 2007). Selain ASI sweet solution yang dapat digunakan untuk mengurangi nyeri adalah glukosa dan sukrosa. Pemberian ASI dapat menurunkan nyeri pada bayi karena ASI mengandung laktosa $7 \%$, gula dalam susu manusia adalah laktosa, yang telah terbukti menjadi analgetik yang efektif karena ASI memiliki efek yaitu rasa yang kuat dari gula menyebabkan respon yang cepat dan singkat yang dapat menenangkan bayi dan produksi endorphin melalui penerima opioid di lidah.
Berbagai penelitian yang mendukung bahwa ASI efektif mengurangi nyeri telah dilakukan antara lain oleh Merisya (2011) yang membandingkan efektivitas ASI dengan non nutritive sucking secara terpisah untuk mengurangi nyeri pada saat prosedur invasif minor pada 98 bayi baru lahir yang hasilnya adalah dua ml ASI diberikan selama dua menit sebelum prosedur invasif minor efektif mengurangi nyeri pada neonatus p-value 0,001 . Begitu pula penelitian Rosali, et al (2014), menjelaskan tentang khasiat ASI yang diberikan pada neonatus untuk mengurangi sakit selama Retinopati Of Prematurity (ROP) Screening, hasilnya adalah kelompok yang menerima ASI memiliki skor PIPP signifikan lebih rendah selama prosedur dengan $p=<0,05$ dibandingkan dengan kelompok kontrol yang tidak diberikan ASI. Sehingga diisimpulkan dari penelitian ini bahwa ASI oral signifikan menurunkkan nyeri setelah screening ROP. Sama halnya dengan penelitian yang dilakukan oleh Upadhyay et al, (2004) meneliti efek analgesik ASI pada prosedural nyeri pada neonatus cukup bulan, dilaksanakan pada 81 neonatus cukup bulan, sampai 4 minggu usia postnatal, yang membutuhkan pungsi vena untuk pemeriksaan darah. Dua menit sebelum pungsi vena, pada kelompok intervensi 40 bayi menerima $5 \mathrm{ml} \mathrm{ASI}$, sedangkan 41 bayi dalam kelompok kontrol menerima $5 \mathrm{ml}$ air suling sebagai plasebo, hasilnya adalah durasi menangis secara signifikan lebih pendek pada bayi yang diberi ASI, perubahan denyut jantung dan saturasi oksigen secara signifikan lebih rendah pada kelompok ASI, sehingga disimpulkan ASI $5 \mathrm{ml}$ sebelum pungsi vena efektif dalam mengurangi gejala akibat nyeri pada neonatus cukup bulan $p$ value $<0,01$.

Berbagai penelitian yang dilakukan terkait dengan efektifitas glukosa untuk mengurangi nyeri juga sudah dijelaskan dalam beberapa penelitian antara lain adalah penelitian Devaera (2006), yang tujuannya untuk mengetahui efek pemberian $0,5 \mathrm{~mL}$ larutan glukosa $30 \%$ per oral 2 menit sebelum tindakan terhadap skala PIPP saat pengambilan darah tumit bayi baru lahir. Hasil dari penelitian tersebut adalah 73 bayi terbagi dalam kelompok intervensi $(n=37)$ dan kontrol $(n=35)$. Rerata nilai skala PIPP kelompok intervensi lebih rendah dibanding kelompok kontrol oleh kedua penilai, yaitu berturut-turut $(4,5 \pm 3,1)$ dan $(6,3 \pm 4)$ dibanding $(6 \pm 3,1)$ dan $(8,4 \pm 4,5) \quad p<0,05$. Devaera merekomendasikan pemberian larutan glukosa $30 \% 0,5 \mathrm{~mL}$ per oral 2 menit sebelum pengambilan darah melalui tumit bayi baru lahir dapat mengurangi nyeri. 
Dilen dan Elseviers (2010) melakukan penelitian yang bertujuan untuk mengetahui apakah glukosa efektif untuk menurunkan nyeri pada bayi baru lahir yang dilakukan pengambilan darah vena. Dilen dan Elseviers menyimpulkan bahwa glukosa $30 \%$ oral $2 \mathrm{~mL}$ yang diberikan 2 menit sebelum tindakan venipuncture lebih efektif menurunkan nyeri pada bayi baru lahir dibandingkan dengan air steril.

Sajedi, Kashaninia, Rahgozar dan Radrazm (2006) melakukan penelitian tentang efisiensi oral glukosa untuk mengurangi nyeri intramuskuler neonatus cukup bulan. Enam puluh empat neonatus cukup bulan dibagi menjadi dua kelompok yaitu kelompok oral glukosa 30\% diberikan $2 \mathrm{ml}$, dan kelompok bayi yang diberikan $2 \mathrm{ml}$ air steril 2 menit sebelum injeksi, Penilaian skor nyeri dengan menggunakan NIPS 3 menit setelah injeksi. Hasilnya adalah skor nyeri neonatus yang diberikan glukosa $30 \%$ menurun signifikan $(p=0,000)$ dibandingkan dengan neonatus yang diberikan air steril, begitu juga dengan heart rate menurun signifikan $(p=0,002)$ dibanding neonatus yang diberikan air steril, sehingga penelitian ini menyimpulkan bahwa oral glukosa 30\% yang diberikan 2 menit sebelum injeksi efektif mengurangi nyeri neonatus yang dilakukan injeksi.

Penelitian Badiee (2006) yang tujuannya adalah untuk membandingkan efek glukosa oral dengan plasebo dalam mengurangi nyeri selama venipuncture pada bayi prematur, 36 bayi prematur usia gestasi 28-34 minggu dibagi menjadi dua kelompok yaitu kelompok intervensi yang diberikan glukosa $30 \% 1 \mathrm{ml}$ melalui mulut dan kelompok kontrol yang diberikan air steril 1 $\mathrm{ml} 2$ menit sebelum venapuncture dilakukan. Hasil nya skor PIPP secara signifikan lebih rendah pada kelompok glukosa dibandingkan dengan kelompok plasebo $(8,94 \pm 3,013$ VS $11,44 \pm 3,42$ masing-masing, $p<0,001)$. Durasi menangis pada 3 menit pertama secara signifikan lebih rendah di glukosa 30\% dibandingkan dengan kelompok plasebo (masing-masing $24,1 \pm 18,48$ VS 39,6 $\pm 26,8, p=0,002)$. Sehingga kesimpulan penelitian ini adalah $30 \%$ glukosa dapat berguna sebagai analgesik dan aman untuk prosedur minor pada bayi baru lahir prematur.

Ling, Mmed, Quah, dan Rostenberghe (2005), melakukan penelitian yang bertujuan untuk mengtahui efek dextrose $30 \%$ dalam menghilangkan sakit neonatus setelah fungsi vena, dibagi menjadi dua kelompok yaitu 26 neonatus diberikan dextrose $30 \%$ sebanyak $2 \mathrm{ml}$, 26 neonatus diberikan air steril $2 \mathrm{ml}$ diberikan 2 menit sebelum venapucture kemudian skor nyeri direkam dengan video rekording, hasil penelitian adalah terjadi penurunan skor nyeri NIPS yang signifikan pada kelompok neonatus yang diberikan dextrose $30 \%(p<0,003)$ dibandingkan dengan neonatus yang diberikan air steril, begitu juga durasi menangis lebih rendah pada kelompok neonatus yang diberikan dextrose $30 \%$ dbandingkan diberikan air steril $(p<0,003)$. Kesimpulan penelitian ini adalah oral dextrose $30 \%$ yang diberikan 2 menit sebelum venapucture efektif menurunkan nyeri neonatus pada prosedur invasif minor.

Shadkam dan Lotfi (2008), melakukan penelitian yang bertujuan untuk untuk membandingkan efek pengurang rasa nyeri dari krim EMLA dengan glukosa oral selama venipunctur pada 220 bayi baru lahir. 106 bayi menerima EMLA pada kulit dan oral placebo (air steril) dan 114 menerima oral glukosa 30\% dan plasebo (Vit A+D) pada kulit. Hasil menunjukkan bahwa skor NIPS secara signifikan lebih rendah pada kelompok glukosa dibandingkan dengan kelompok $(p=<0,001)$. Untuk durasi menangis 2 menit pertama secara signifikan lebih rendah pada kelompok glukosa dibanding kelompok EMLA $(p<0.01)$. Shadkam dan Lotfi menjelaskan bahwa dibandingkan dengan krim EMLA, oral glukosa dapat lebih efektif, ditoleransi dan nyaman dalam mengurangi rasa sakit akibat venipunctur pada neonatus. Hasil penelitian ini menyimpulkan bahwa oral glukosa lebih baik dari EMLA krim, alasan oral glukosa lebih baik dari EMLA krim adalah karena oral glukosa mendorong pelepasan endorphin yang mempunyai pengaruh menginduksi pusat analgesik dibandingkan dengan EMLA krim yang hanya bekerja secara lokal dikulit.

Larutan glukosa merupakan salah satu intervensi non farmakologi yang dapat digunakan untuk menurunkan resiko nyeri yang dialami bayi baru lahir. Larutan glukosa yang diberikan melalui oral atau mulut neonatus dimana mulut merupakan indra untuk merasakan berbagai rasa termasuk rasa manis. Rangsangan menurunkannya rasa nyeri yang dimunculkan pada indra perasa manis diperkirakan berhubungan dengan mekanisme preabsorbsi dari rasa manis (Triani, 2006). Penelitian lain yang dilakukan oleh Gradin, et al. (2002) menjelaskan rasa manis yang ditimbulkan oleh larutan glukosa mengakibatkan terangsangnya pelepasan endorpin yang dikeluarkan oleh opioid endogen sebagai morpin alamiah dan atau efek pada area lokal sebagai adanya rasa manis pada lidah. Hal inipun sependapat dengan penelitian yang dilakukan Okan, et al. (2007) yang menjelaskan bahwa larutan glukosa dapat menimbulkan efek 
terhadap tingkat nyeri yang berguna sebagai analgetik adalah teraktifasi opioid endogen melalui rasa manis yang berada pada larutan glukosa tersebut. Efek yang dirasakan akan mencapai puncaknya pada 2 menit setelah pemberian dan akan berkurang setelah 5 menit.

Berdasarkan hasil penelitian-penelitian diatas dapat disimpulkan bahwa larutan glukosa dapat merangsang pengeluaran endorphin oleh opioid endogen yang akan memodulasi nyeri sehingga implus nyeri dapat dihambat. Potter dan Perry (2006) menjelaskan bahwa alur saraf desenden mempunyai aktivitas melepaskan opiat endogen, seperti endorfin dan dinorfin yang merupakan suatu pembuluh nyeri alami yang berasal dari tubuh yang akan membelokkan pesan nyeri dari sumber yang sama. Menurut Gibbin dan Steven (2001) dalam penelitiannya menjelaskan efek sukrosa yang menenangkan dan menghilangkan rasa nyeri diperkirakan karena jalur opioid endogen diaktifkan oleh rasa manis. Efek orogustatory sukrosa telah dibuktikan pada bayi baru lahir hewan dan pada bayi prematur manusia yang mengalami prosedur menyakitkan. Penelitian lain yang dilakukan oleh Blass (1997) menunjukkan bahwa rasa susu, larutan manis, ASI, menginduksi antinosisepsi, secara signifikan menurunkan rentang tangis pada bayi. Susu dan larutan manis diduga melakukan hal tersebut melalui jalur opioid.

Baik ASI maupun glukosa adalah samasama merupakan larutan manis. Rasa manis mempunyai pengaruh terhadap respon nyeri, mekanisme ini terjadi karena larutan manis yang terdapat dalam ASI maupun glukosa dapat menginduksi analgetik jalur opioid endogen yang menyebabkan transmisi nyeri tidak sampai ke otak, sehingga persepsi dan sensasi nyeri tidak dirasakan bayi saat dilakukan pemasangan infus maupun pengambilan spesimen darah atau pada saat prosedur invasif minor lainnya, oleh karena itu ASI dan glukosa yang diberikan dapat dipakai untuk mencegah trauma pada bayi yang dilakukan tindakan invasif minor.

Manfaat atraumatic care pada neonatus dalam hal ini adalah pemberian kombinasi NNS dengan ASI dan kombinasi NNS dengan glukosa $30 \%$ dapat menurunkan nyeri pada neonatus, sehingga respon nyeri pada neonatus yang dilakukan pemasangan infus atau pengambilan spesimen darah menjadi menurun yang dapat dilihat dari neonatus tidak menangis pada saat dilakukan. Prinsip atraumatic care yang dilakukan perawat dalam hal ini adalah mengurangi nyeri yang merupakan tindakan yang harus dilakukan dalam perawatan anak atau neonatus. Proses pengurangan rasa nyeri sering tidak bisa dihilangkan secara cepat akan tetapi dapat dikurangi melalui berbagai tehnik seperti distraksi, relaksasi, dan imaginary. Pemberian kombinasi NNS dengan ASI dan NNS dengan glukosa dapat sebagai distraksi pada saat dilakukan tindakan invasif. Apabila tindakan pencegahan tidak dilakukan maka cidera dan nyeri akan berlangsung lama pada anak sehingga dapat menggangu pertumbuhan dan perkembangan anak (Alimul, 2008).

Sesuai dengan konsep teori comfort dari Katharina C. Kolkaba yang menjelaskan bahwa comfort diartikan sebagai status menjadi kuat dengan terpenuhinya kebutuhan manusia terhadap relief, ease, dan transendence pada konteks pengalaman yang meliputi aspek fisik, psikospiritual, sosial, dan lingkungan. Ketika keempat konsep comfort disandingkan dengan tiga tipe comfort maka terbentuklah struktur taxonomic yang kompleks yang menghasilkan rasa nyaman (Alligood \& Tomey, 2010).

Berdasarkan hal tersebut maka menurut peneliti pemberian ASI atau glukosa yang dapat menurunkan respon nyeri neonatus adalah merupakan suatu tindakan keperawatan untuk mencapai kenyamanan pada neonatus. Pada saat akan dilakukan pemasangan infus atau pengambilan spesimen darah peneliti juga meletakkan neonatus pada radiant warmer dengan tujuan supaya neonatus tidak hipotermi dan kenyamanan neonatus tetap terjaga walaupun pada ruangan yang dingin hanya menggunakan pempers saja.

Meskipun secara statistik hasil penelitian tidak menunjukkan perbedaan yang signifikan antara kelompok kombinasi NNS dengan ASI dan kelompok NNS dengan glukosa 30\% akan tetapi terdapat perbedaan rata-rata antara kedua kelompok tersebut, yakni kelompok glukosa 30\% memiliki nilai rata-rata lebih kecil $(1,19)$ dibandingkan dengan kelompok kombinasi NNS dengan ASI (2,50), dengan perbedaan rata-rata 1, 31 pada kepercayaan 95\%, hal ini dapat diasumsikan bahwa glukosa $30 \%$ lebih baik dalam penurunan nyeri dibandingkan kombinasi NNS dengan ASI. Glukosa adalah larutan yang manis karena didalamnya terkandung gula, ASI juga merupakan sweet solution akan tetapi apabila dirasakan rasa glukosa lebih manis dibandingkan dengan ASI, oleh karena itu dapat diasumsikan glukosa lebih dapat mengurangi nyeri dibandingkan dengan ASI.

Walaupun berdasarkan nilai rata-rata perbandingan respon nyeri kombinasi NNS dengan ASI dan NNS dengan glukosa 30\% menunjukkan adanya perbedaan tetapi kalau dilihat dari nilai $p$-value bahwa pemberian 
kombinasi NNS dengan ASI dan NNS dengan glukosa $30 \%$ pada saat dilakukan pemasangan infus atau pengambilan spesimen darah tidak memiliki perbedaan bermakna. Hal ini dapat diasumsikan bahwa respon nyeri neonatus dapat dipengaruhi oleh beberapa faktor lain seperti umur neonatus, usia gestasi, jenis kelamin neonatus, riwayat dilakukan pemasangan infus atau pengambilan darah, serta jenis penyakit.

\section{SIMPULAN}

1. Usia responden yang paling muda adalah 2 tahun dan yang tertua adalah 28 hari, sebagian besar usia gestasi responden $\geq 37$ minggu, dengan jenis kelamin responden pada kelompok NNS dan ASI sama antara laki-laki dan perempuan, untuk kelompok glukosa $30 \%$ responden terbanyak adalah laki-laki, mayoritas responden sudah pernah mengalami pemasangan infus atau pengambilan spesimen darah sebelumnya, jenis penyakit terbanyak responden adalah kelainan bawaan.

2. Respon nyeri neonatus yang diukur dengan skala nyeri NIPS pada saat pemasangan infus atau pengambilan spesimen darah menunjukkan hasil tidak ada perbedaan yang signifikan antara pemberian kombinasi NNS dengan ASI dan NNS dengan glukosa 30\% artinya baik kombinasi NNS dengan ASI atau kombinasi NNS dengan glukosa 30\% sama-sama dapat digunakan untuk manejemen non farmakologi pada neonatus yang dilakukan pemasangan infus atau pengambilan spesimen darah.

\section{SARAN}

1. Bagi Pelayanan Kesehatan

Dalam pemberian layanan kesehatan, khususnya pemberian tindakan keperawatan yang menimbulkan nyeri atau cidera perlu adanya manejemen nyeri dan penerapan atraumatic care untuk memberikan kenyamanan bagi pasien. Pemberian kombinasi NNS dengan ASI atau kombinasi NNS dengan glukosa $30 \%$ perlu disosialisasikan sebagai alternatif manajemen nyeri non farmakologi pada neonatus yang dilakukan tindakan invasif, akan tetapi karena ASI adalah makanan terbaik bagi neonatus dan bayi, ASI lebih efektif dan efisien, ASI lebih murah dan mudah didapatkan (cost efektif), ASI juga menjaga hubungan psikologis ibu dan bayi tetap terjaga dan untuk mensukseskan program pemerintah tentang ASI eksklusif yang terdapat dalam peraturan pemerintah no 33 tahun 2012 maka disarankan untuk tetap memprioritaskan pemberian ASI dalam manejemen nyeri neonatus yang dilakukan pemasangan infus atau pengambilan spesimen darah.

2. Bagi institusi pendidikan

Penelitian ini dapat memberikan informasi bagi profesi keperawatan dalam memberikan kenyamanan dan penerapan atraumatic care.

3. Bagi Penelitian

Peneliti merekomendasikan untuk dilakukan penelitian dengan jumlah sampel lebih besar, perawat yang sudah berkompetensi dalam melakukan pemasangan infus atau pengambilan spesimen darah, sehingga tidak mempengaruhi durasi jumlah tusukan yang dapat mempengaruhi nyeri neonatus.

\section{DAFTAR PUSTAKA}

Alimul Aziz. 2008. Pengantar Ilmu Keperawatan Anak. Jakarta: Salemba Medika.

Badiee, Z. 2006. Oral Hypertonic Glucose, for Analgesia in The Premature Newborns. Pak J Psysiol, 2 (2), 12-14.

Bolin. 2011. Hubungan Penerapan Atraumatik Care dalam Pemasangan Infus terhadap Respon Kecemasan pada Anak yang Mengalami Hospitalisasi di Irnan D Anak Rumah Sakit dr. M.djamil. Tesis, Padang, Universitas Andalas

Blass, E.M. 1997. Milk-induced hipoalgesi in human newborn. Pediatrics, 99.825-829
Dilen, B \& Elseviers, M. 2010. Oral Glucose Solution as Pain Relief in Newborns: Results of A Clinical Trial. Journal Compilation, 37 (2) 98-105.

Dharma, K.K. 2011. Metodologi Penelitian Keperawatan. Jakarta: Trans Info Media.

Depkes RI. 2010. Situasi Penyandang Disabilitas. Buletin Jendela Data dan Informasi Kesehatan.

Gibbin, S., \& Stevens, B. 2001.Mecahniss of Sucrose and Nonnutritive Sucking in Procedural Pain Management in Infants. Pain Rest Management 2001, 6(1), 21-28. 
Gradin, M., Ericsson, M., Holmqvist, G., Holstein, A, \& Schollin, J. 2002. Pain reduction at venipuncture $n$ newborns: oral glukosa compared with local anasthetic cream. Pediatrics 2002, 110 (1053), 10531057

Hockenberry, M. J., \& Wilson, D. 2009. Essensials of Pediatrics Nursing. (8th ed.). St Louis: Mosby Elsevier.

Hockenberry, M.J., \& Wong, D. 2009. Buku Ajar Keperawatan Pediatrik Wong. Edisi 6, vol 2. Jakarta: EGC.

Ling, M.J,. Mmed, Quah, B.S., FRCP \& Rostenberghe, V. 2005. The safety and efficacy of oral dextrose for relieving pain following venepuncture in neonates. Med J Malaysia, 60 (2), 140-145

Malarvizhi, G., Vasta, M., Roseline, M., Nithin, S. \& Paul, S. 2012. Interrater Reliability of Neonatal Infant Pain Scale as Multidimentional Behavioral Pain Tool. Nitte University of Journal of Helath Science 2012, 26-30.

Okan, P., Coban, A., Ince, Z., Yapici, Z., \& Can, G. 2007. Analgesia in Preterm Newborns: The Comparative Effects of Sucrose and Glucose. Journal of Eur J Pediatr, 166:1017-1024.

Obu, H.A., \& Chinawa, J.M. 2014. Neonatal Analgesia: A Negected Issue in The Tropis. Niger Med J, 55 (3) 183-187.

Polit, d.F. \& Beck, C.T. 2012. Nursing Research. 9th edition. Lippincot: Williams \& Walkins.

Potter, A.G. \& Perry, P.A. 2006. Buku Ajar Fundamental Keperawatan: Konsep, Proses, \& Praktik. Edisi 4, Volume 2. Jakarta: EGC.

Rosali, S.L., Nesargi, S., Mathew, S., Vasu, U., Rao, S., \& Bhat, S. 2014. Efficacy of Expressed Breast Milk in Reducing Pain During ROP Screening: A Randomized Controlled Trial. Oxford University Press.

Sajedi, F., Kashaninia,Z., Rahgozar, M., \& Radrazm, L. 2006. The Efficacy of Oral Glucose for Relieving Pain Following Intramuscular Injection in Term Neonates. Acta Medica Iranica, 44 (5) 316-322.

Setiadi. 2007. Konsep dan Penulisan Riset Keperawatan. Yogyakarta: Graha Ilmu.

Simonse, E., Mulder, P.G.H., \& Beek, R. 2012. Analgesic Effect of Breast Milk Versus
Sucrose for Analgesia During Heel Lance in Late Preterm Infants. Journal of American Academy of Pediatrics, 129 (4) 657-663.

Sahoo, J.J., Rao, S., Nesargi, S., Ranjit, T., Ashok, C., \& Bhat, S. 2013. Expressed Breast Milk vs 25\% Dextrose in Procedural Pain in Neonates: A Double Blind Randomized Controlled Trial. Journal Department of Neonatology, 50, 203-207.

Sabety, F., Yaghoobi, M., Torabizadeh, M., Javaherizadeh, H., Haghighizadeh, M.H., \& Muhammadian, F. 2013. Which is Better for Pain Reduction before Venipuncture:Glucose, Lidocaine or Expressed Breast Milk?. Journal HK J Paediatr (new series); 18:19-23.

Shadkam, N.M \& Lotfi, M.H. 2008. Pain Reducing in Icteric Newborns while Venipuncturing: Comparison of Local Anasthetic Cream with Orally Glucose. Acta Medica Iranica, 46 (1), 59-64.

Shadkam, N.M., Lotfi, M.H \& Aarafi, H. 2007. Comparison of The Effect of Local Anesthetic Cream and Orally Administered Glucose Solution in Reduction of Pain in Icteric Newborns During Venipuncture. Journal Iranian Red Crescent Medical. 9 (2), 93-98.

Tomey, A.M \& Alligood, M.R. 2010.Nursing Theorists and Their Work. St Louis, Missouri: Elsevier Mosby.

Triani, E., \& Lubis, M. 2006. Penggunaan Analgesia Nonfarmakologis Saat Tindakan Invasif Minor pada Neonatus. Sari Pediatri, 8, (2), 107-111.

Upadhyay,A., Aggarwal, R., Narayan,S., Joshi, M., Paul,V..K., \& Deorari, A.K. 2004. Analgesic Effect of Expressed Breast Milk in Procedural Pain in Term Neonates: A Randomized, Placebo-Controlled, DoubleBlind Trial. Acta pediatr, 93: 518-522.

World Health Organization. 2012. World Health Statistic. France: WHO library cataloguing-in-publication-data

Yang, M.C.O., Chen, I.L., Chen, C.C., Chung, M.Y., Chen, F.S., \& Huang, C. H. 2012. Expressed breast milk for procedural pain in preterm neonates: a randomized, doubleblind, placebo-controlled trial. Foundation Acta Padiatrica. 102, 15-21. 